\title{
ANALISIS KONDISI METEOROLOGI TERKAIT KEJADIAN KEBAKARAN HUTAN DI LERENG GUNUNG MERBABU
}

\author{
Anendha Destantyo Nugroho', Muhammad Zakky Faza ${ }^{2}$, Paulus Agus Winarso ${ }^{3}$ \\ Sekolah Tinggi Meteorologi Klimatologi dan Geofisika \\ Jl. Perhubungan I No. 5, Pondok Betung, Pondok Aren, Pd. Betung, Tangerang Selatan, Kota \\ Tangerang Selatan, Banten 15221, Indonesia \\ Email : nendha27@gmail.com
}

\begin{abstract}
There was a fire in the land and forest of the Gunung Merbabu National Park in Semarang Regency, Central Java. The fire burned the land on Sunday, October 142018 afternoon, the area of land in the forest area of Mount Merbabu which was burned reached 100 hectares. The number is predicted to increase because the flames have not been extinguished. Fires in the Mount Merbabu National Park not only damage the forest ecosystem. The fire also decided the pipeline of clean water flowing to a number of hamlets in Batur Village. Land and forest fires are supported by meteorological drought, so studies need to be done to find out the magnitude of meteorological factors that support forest fires and the extent of burning areas. This research was conducted by analyzing the results of meteorological observations obtained from AWS (Automatic Weather Station) installed not far from the slopes of Mount Merbabu, including AWS Pakem Yogyakarta, AWS Borobudur Magelang, AWS Undip Semarang. In addition to the analysis of surface observation data, this study also analyzes the atmospheric conditions of surface wind maps, Rainy Days, and observations of satellite images during the occurrence of land and forest fires in Mount Merbabu National Park.
\end{abstract}

Keywords: Meteorology, Fire, Forest, Satellite

\begin{abstract}
Abstrak: Terjadi kebakaran lahan dan hutan Taman Nasional Gunung Merbabu di Kabupaten Semarang, Jawa Tengah. Api membakar lahan pada Minggu 14 Oktober 2018 sore, luas lahan di kawasan hutan Gunung Merbabu yang terbakar mencapai 100 hektar. Jumlah itu diprediksi bertambah karena kobaran api belum berhasil dipadamkan. Kebakaran di Taman Nasional Gunung Merbabu tidak hanya merusak ekosistem hutan. Kebakaran juga memutuskan jaringan pipa air bersih yang mengalir ke sejumlah dusun di Desa Batur. Kebakaran lahan dan hutan tersebut didukung oleh faktor kekeringan meteorologi, sehingga perlu dilakukan kajian untuk mengetahui besarnya faktor meteorologi yang mendukung terjadinya kebakaran hutan serta meluasnya area yang terbakar. Penelitian ini dilakukan dengan analisis hasil pengamatan meteorologi yang didapatkan dari AWS (Automatic Weather Station) yang terpasang tidak jauh dari lereng Gunung Merbabu, antara lain AWS Pakem Yogyakarta, AWS Borobudur Magelang, AWS Undip Semarang. Selain analisis dari data hasil pengamatan permukaan, penelitian ini juga melakukan analisis kondisi atmosfer peta angin permukaan, Hari Tanpa Hujan, serta pantauan citra satelit saat terjadinya kebakaran lahan dan hutan di Taman Nasional Gunung Merbabu.
\end{abstract}

Kata kunci: Meteorologi, Kebakaran, Hutan, Satelit 


\section{PENDAhUluan}

Kebakaran hutan merupakan fenomena yang sering terjadi di Indonesia (Gellert, 1998). Periode bulan terjadinya kebakaran lahan dan hutan di Indonesia biasanya terjadipada musim kemarau, yaitu pada bulan Agustus,September, dan Oktober, maupun pada masaperalihan atau transisi (Bahri 2002; Rianawati, 2005; Syaufina dan Sukmana, 2008). Faktor iklim dan cuaca mempunyai kaitan dengan kejadian kebakaran hutan. Iklim menentukan seberapa banyak jumlah bahan bakar yang tersedia untuk pembakaran dan menentukan seberapa lama maupun seberapa parah periode kebakaran (fire season) berlangsung (Chandler et al., 1983).

Kebakaran melanda hutan di lereng Gunung Merbabu di wilayah Kecamatan Getasan, Kabupaten Semarang, Minggu, 14 Oktober 2018. Petugas Badan Penanggulangan Bencana Daerah (BPBD) Boyolali Jawa Tengah mengemukakan, kebakaran terjadi siang hari sekitar pukul 13.00 WIB. Kebakaran lahan hutan Taman Nasional Gunung Merbabu di wilayah Kecamatan Getasan, Kabupaten Semarang tidak hanya merusak ekosistem melainkan juga memutuskan jaringan pipa air bersih yang mengalir ke beberapa dusun di Desa Batur, Kecamatan Getasan. Dari informasi yang dihimpun KR Jogja sekira 280 kepala keluarga (KK) di Dusun Nglelo dan Dusun Thekelan, Desa Batur kesulitan air bersih. Untuk mendapatkan air bersih, mereka harus mengambil air ke dusun lainnya. Dari informasi yang dihimpun KRJOGJA.com sekira 280 kepala keluarga (KK) di Dusun Nglelo dan Dusun Thekelan, Desa Batur kesulitan air bersih. Untuk mendapatkan air bersih, mereka harus ngangsu (mengambil air) ke dusun lainnya.

Penulis melakukan penelitian ini bertujuan untuk mengetahui kondisi meteorologi saat terjadinya kebakaran lahan dan hutan di Taman Nasional Gunung Merbabu. Meskipun fenomena ini tidak menimbulkan korban jiwa dan kerusakan material, tetapi kejadian cuaca ekstrem ini perlu dilakukan analisis tentang kondisi atmosfer saat dan sebelum kejadian berlangsung. Sehingga, apabila pada waktu mendatang terjadi kebakaran hutan pada skala yang lebih besar, maka dapat diketahui kondisi meteorologi sebelum kejadian, untuk mencegah adanya korban jiwa dan kerusakan material. Analisis kajian ini menggunakan data data angin permukaan/streamline untuk mengetahui pergerakan massa udara serta dilakukan analisis data AWS (Automatic Weather Station) yang terpasang di kawasan Candi Borobudur. Selain itu dilakukan juga analisis Hari Tanpa Hujan (HTH) dan citra satelit himawari-8 pada saat terjadinya kebakaran lahan dan hutan di Taman Nasional Gunung Merbabu untuk mengetahui cakupan luas awan.

Automatic Weather Station adalah alat pengukur cuaca otomatis dan pengembangan dari stasiun cuaca versi tradisional yang berfungsi untuk menghemat tenaga kerja manusia atau memungkinkan pengukuran di daerah-daerah terpencil. Automatic Weather Station dapat merekam dan memantau perubahan cuaca secara langsung dan otomatis. Hasil dari pengukuran dapat dipantau dalam bentuk statistik. Sebagian besar dari Automatic Weather Station memiliki bagian-bagian sebagai berikut:

- Termometer untuk mengukur suhu

- Anemometer untuk mengukur kecepatan angin

- Wind Meter untuk mengukur arah angin

- Hygrometer untuk mengukur kelembaban

- Pyranometer untuk mengukur radiasi matahari

- Rain Gauge untuk mengukur curah hujan

- Data Logger untuk menyimpan data pengukuran

- Barometer untuk mengukur tekanan atmosfir, dan

- Berberapa AWS mempunyai Ceilometer untuk mengukur ketinggian awan 
Tidak seperti stasiun cuaca manual, Automatic Weather Station tidak dapat mememantau jenis dan jumlah awan.

Satelit himawari-8 merupakan satelit pengembangan dari satelit MTSAT-2. Satelit ini dikembangkan oleh Japan Meteorology Agency (JMA) yang diluncurkan pada tahun 2014 dan mulai dioperasionalkan tahun 2015.

\section{METODE PENELITIAN}

\subsection{Lokasi Penelitian}

Penelitian ini dilakukan di Taman Nasional Gunung Merbabu yang terletak di provinsi Jawa Tengah. Secara geografis Taman Nasional Gunung Merbabu terletak pada $7,5^{\circ}$ LS dan $110,4^{\circ} \mathrm{BT}$, dengan batas-batas wilayah sebagai berikut :

a) Sebelah Utara : Kabupaten Semarang;

b) Sebelah Timur : Kabupaten Boyolali;

c) Sebelah Selatan : Kabupaten Yogyakarta

d) Sebelah Barat : Kabupaten Magelang.

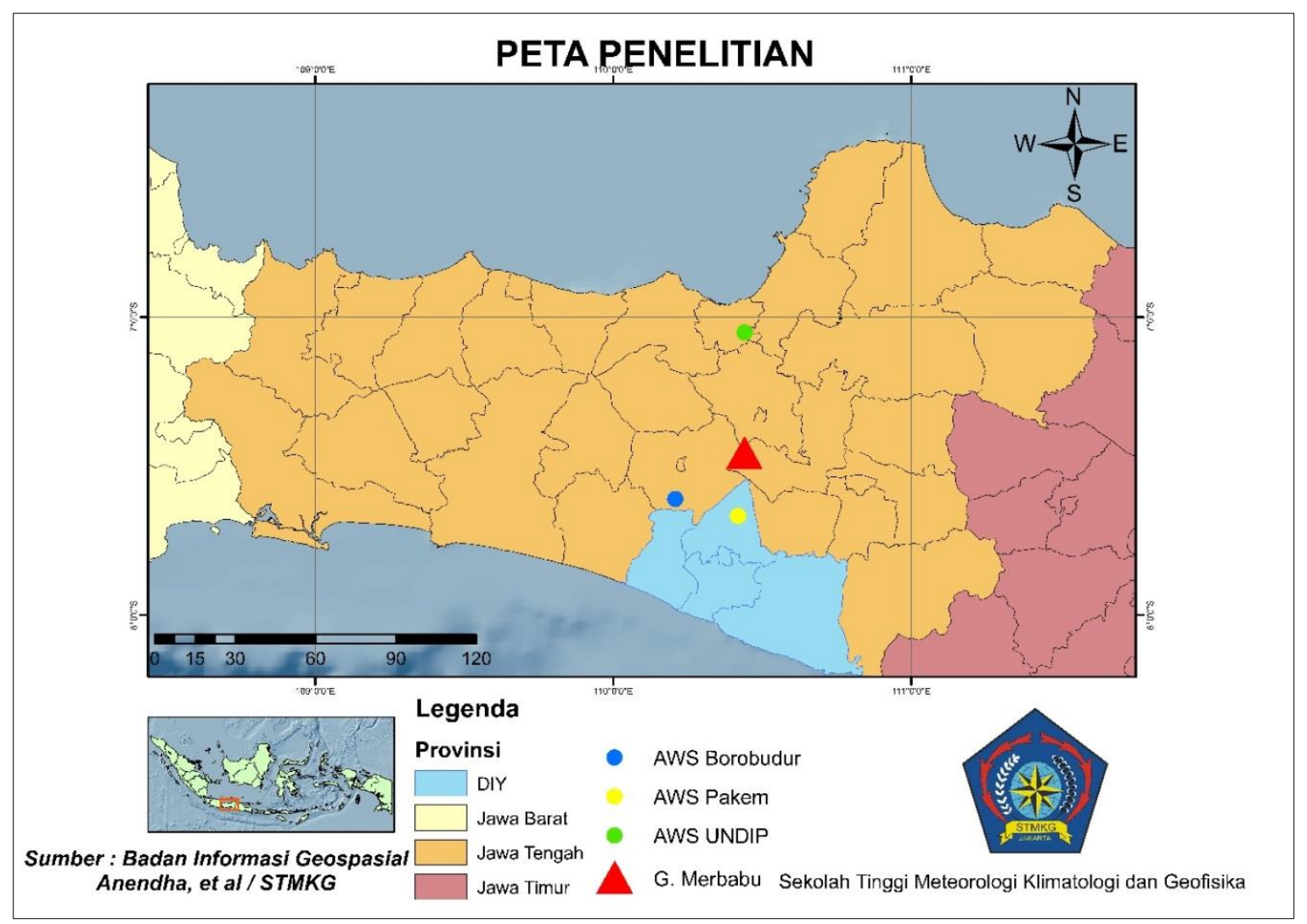

Gambar 1. Peta Wilayah Penelitian

\subsection{Data dan Metode}

Data yang digunakan dalam penelitian ini adalah data AWS (Automatic Weather Station) yang dipasang di kawasan Candi Borobudur diperoleh dari situs AWS Center BMKG (http://202.90.198.212/awscenter/) data yang diperoleh diolah menggunakan perangkat lunak sehingga bisa ditampilkan dengan grafik. Data citra satelit himawari 8 tanggal 14 Oktober 2018 hingga 15 Oktober 2018 yang diperoleh dari (http://www.satelit.bmkg.go.id) kemudian 
diolah menggunakan perangkat lunak SATAID untuk menampilkan cakupan awan yang berada di atas wilayah Taman Nasional Gunung Merbabu.

\section{HASIL DAN PEMBAHASAN}

\subsection{Analisis streamline}

Analisis streamline digunakan untuk mengetahui pola angin yang bertiup pada tanggal 8 Oktober hingga 15 Oktober 2018
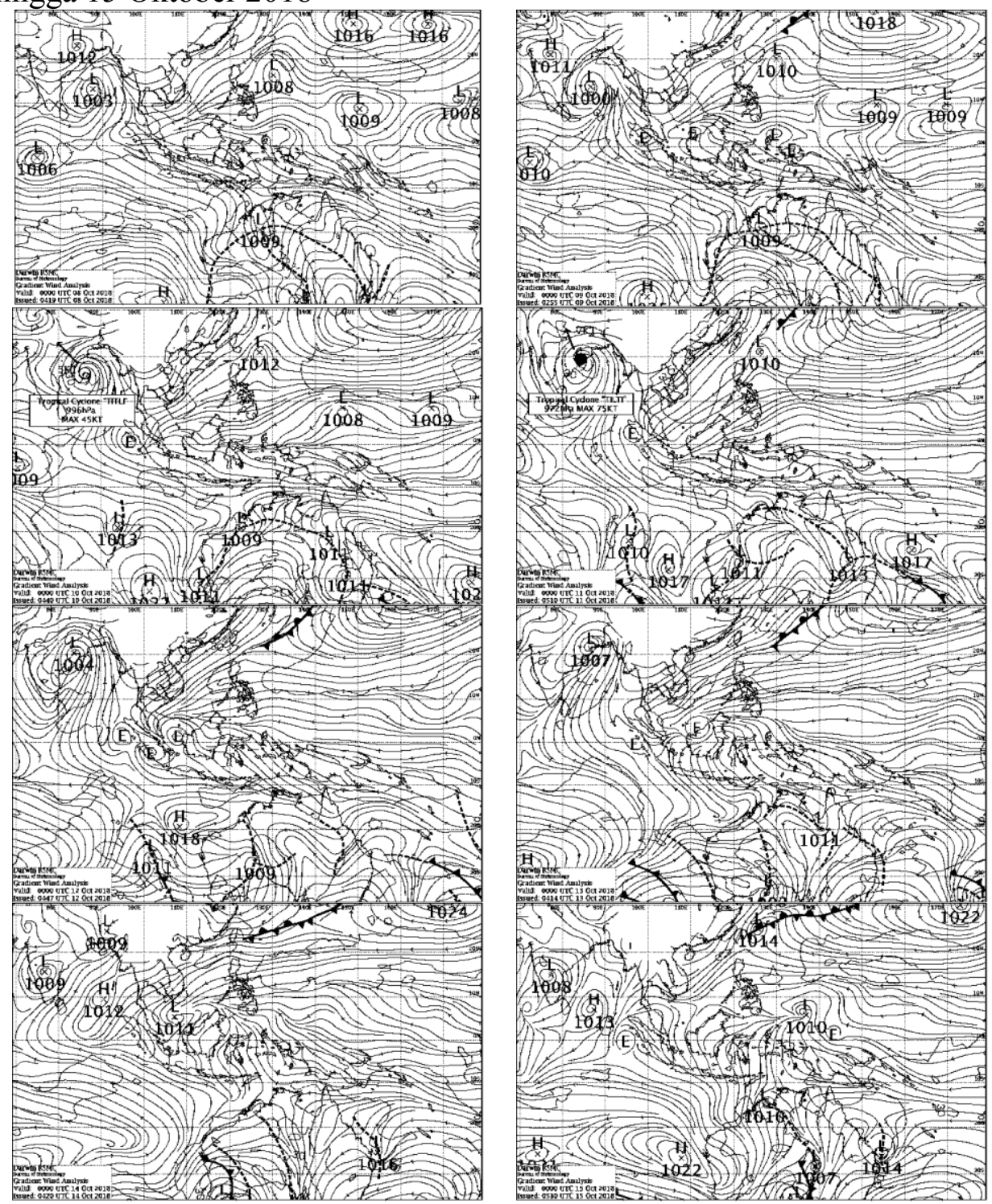

Gambar 2. Peta Streamline Angin Permukaan

Berdasarkan peta streamline angin permukaan pada tanggal 8 Oktober hingga 14 Oktober di atas, menunjukkan terjadi pegerakan massa udara dari Australia yang mengandung uap air sangat sedikit atau bersifat kering. Massa udara tersebut melewati wilayah Jawa Tengah dan sekitarnya sehingga di wilayah Jawa Tengah memiliki suhu udara relatif tinggi dan kelembapan relatif rendah yang dapat mendukung terjadinya kebakaran hutan karena 
tumbuhan dan semak belukar di sekitar Taman Nasional Gunung Merbabu menjadi kering dan sangat mudah untuk terbakar.

\subsection{Analisis data AWS (Automatic Weather Station)}

Analisis data AWS (Automatic Weather Station) dilakukan pada 3 tempat, antara lain :

- AWS Borobudur Magelang

- AWS Pakem Yogyakarta

- AWS Universitas Diponegoro Semarang

\subsubsection{Analisis Suhu Udara}

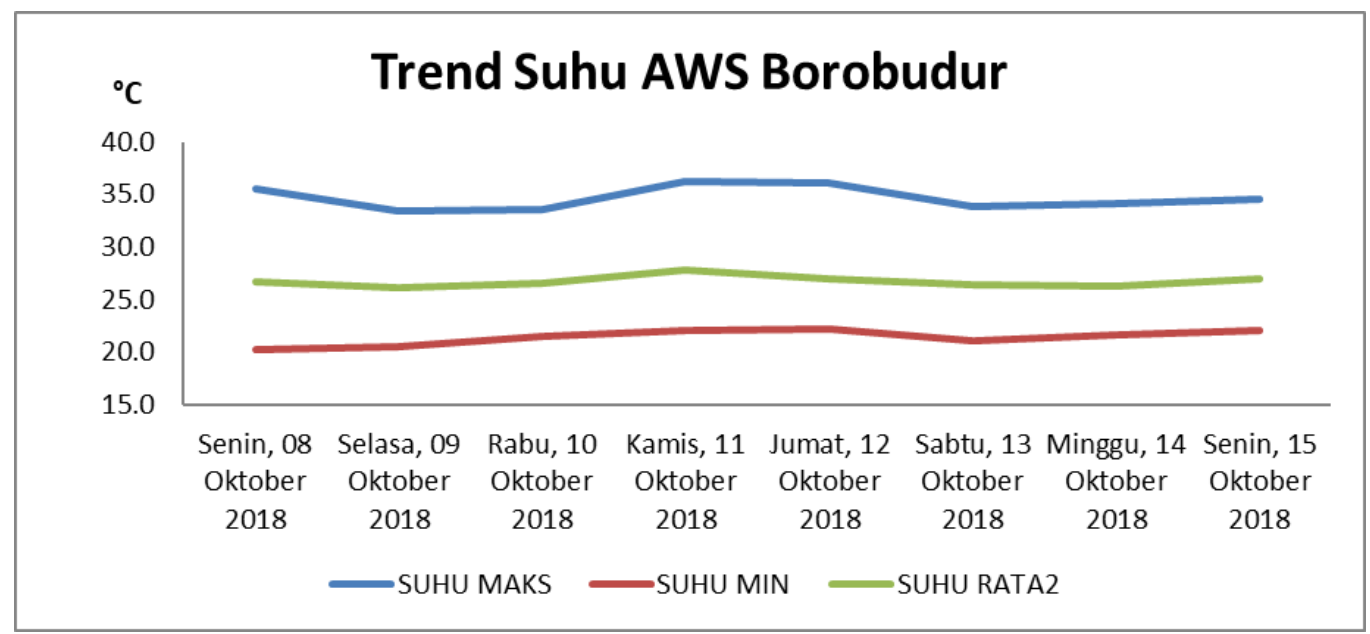

Gambar 3. Trend Suhu AWS Borobudur

Suhu udara pada tanggal 8 Oktober hingga tanggal 15 Oktober 2018 menunjukkan bahwa suhu maksimum yang terukur pada AWS (Automatic Weather Station) Borobudur mencapai $36.5^{\circ} \mathrm{C}$ dengan rata-rata suhu udara sekitar $26^{\circ}-27^{\circ} \mathrm{C}$ dan suhu minimum sebesar $21^{\circ} \mathrm{C}$. Dari hasil pengukuran tersebut dapat disimpulkan bahwa kondisi suhu udara pada tanggal 8 Oktober hingga 15 Oktober 2018 tinggi atau panas dan dapat mendukung terjadinya kebakaran lahan dan hutan di Taman Nasional Gunung Merbabu.

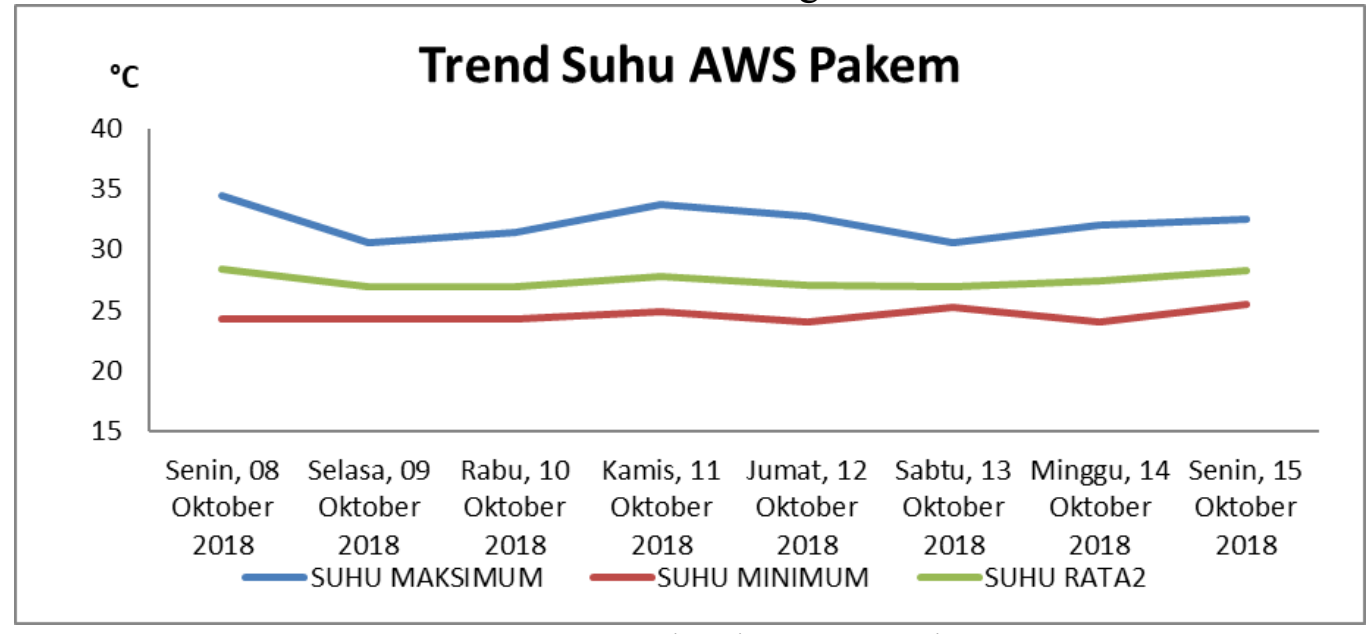

Gambar 4. Trend Suhu AWS Pakem 
Suhu udara pada tanggal 8 Oktober hingga tanggal 15 Oktober 2018 menunjukkan bahwa suhu maksimum yang terukur pada AWS (Automatic Weather Station) Pakem mencapai $34.4^{\circ}$ $\mathrm{C}$ dengan rata-rata suhu udara sekitar $27^{\circ}-28^{\circ} \mathrm{C}$ dan suhu minimum sebesar $24^{\circ} \mathrm{C}$. Dari hasil pengukuran tersebut dapat disimpulkan bahwa kondisi suhu udara pada tanggal 8 Oktober hingga 15 Oktober 2018 tinggi atau panas dan dapat mendukung terjadinya kebakaran lahan dan hutan di Taman Nasional Gunung Merbabu.

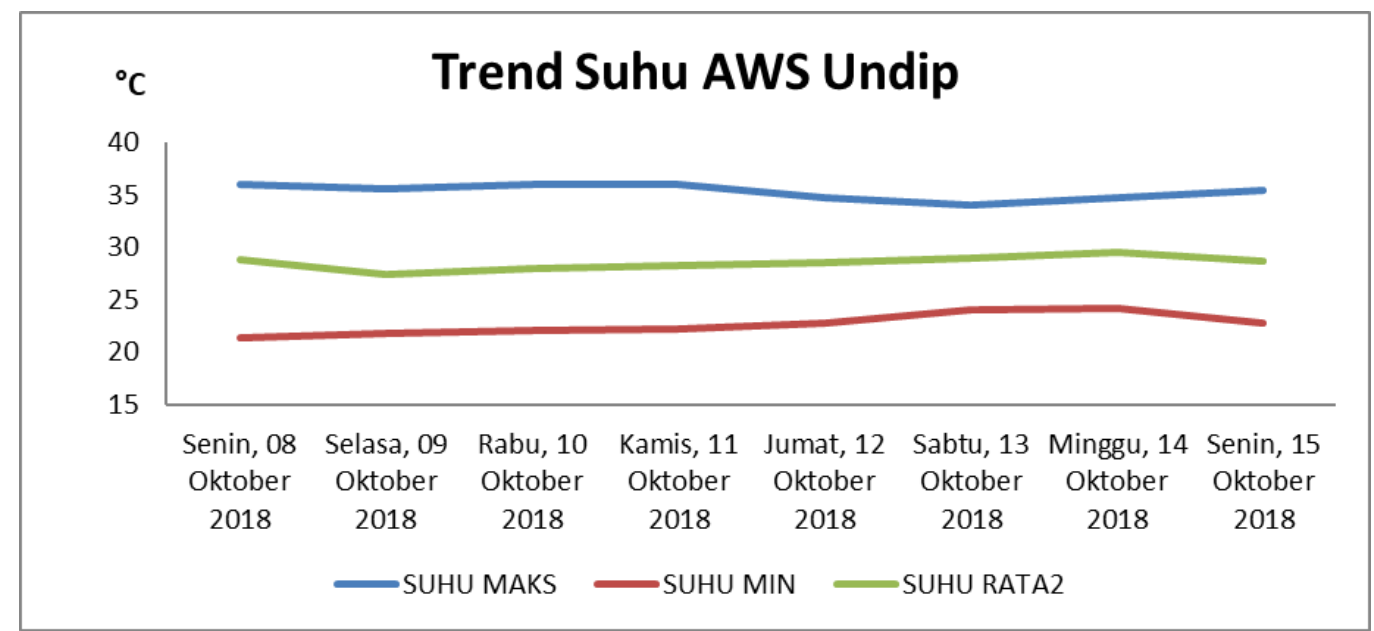

Gambar 5. Trend Suhu AWS Undip

Suhu udara pada tanggal 8 Oktober hingga tanggal 15 Oktober 2018 menunjukkan bahwa suhu maksimum yang terukur pada AWS (Automatic Weather Station) Undip mencapai $36^{\circ} \mathrm{C}$ dengan rata-rata suhu udara sekitar $28^{\circ}-29^{\circ} \mathrm{C}$ dan suhu minimum sebesar $22^{\circ} \mathrm{C}$. Dari hasil pengukuran tersebut dapat disimpulkan bahwa kondisi suhu udara pada tanggal 8 Oktober hingga 15 Oktober 2018 tinggi atau panas dan dapat mendukung terjadinya kebakaran lahan dan hutan di Taman Nasional Gunung Merbabu.

\subsubsection{Analisis RH (Relative Humidity)}

Kelembapan udara yaitu banyaknya kadar uap air yang ada di udara. Kelembapan dibagi menjadi tiga istilah, yaitu (Gunarsih, 2001):

1) Kelembapan mutlak: massa uap air yang berada dalam satu satuan udara yang dinyatakan dalam gram $/ \mathrm{m} 3$.

2) Kelembapan spesifik: perbandingan jumlah uap air di udara denagn satuan massa udara yang dinyatakan dalam gram $/ \mathrm{kg}$.

3) Kelembapan relatif: merupakan perbandingan jumlah uap air di udara dengan jumlah maksimum uap air yang dikandung panas dan temperatur tertentu yang dinyatakan dalam\%. 


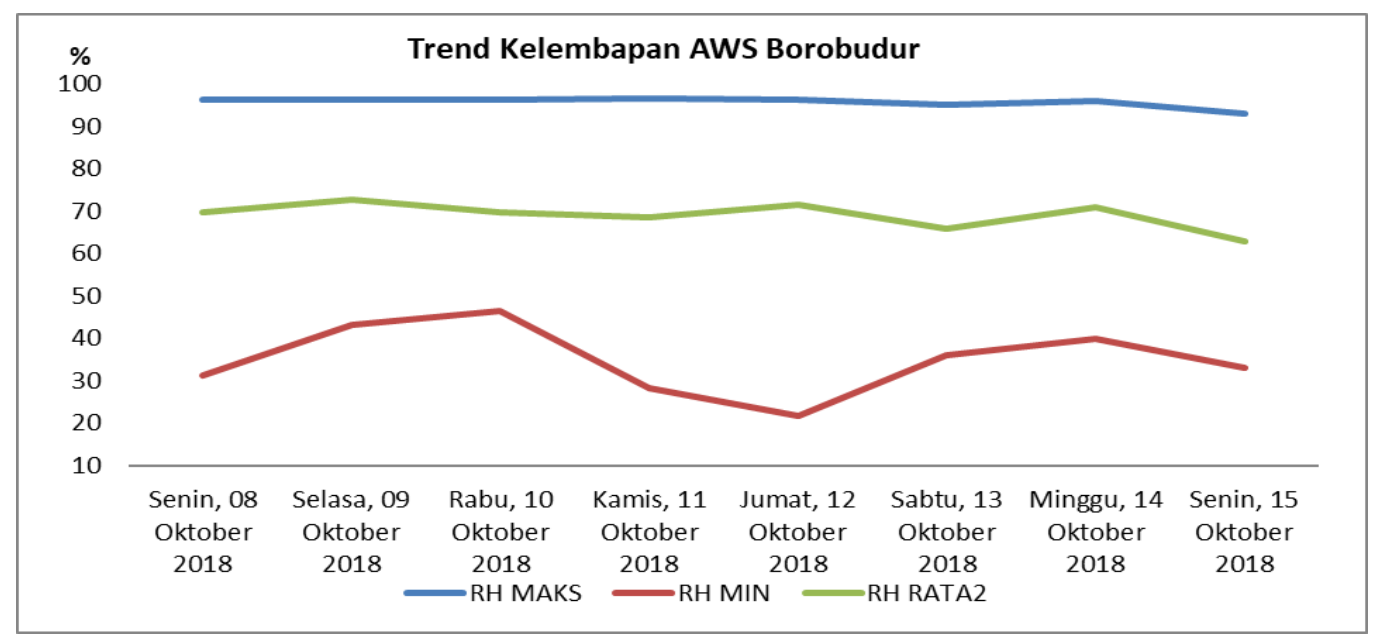

Gambar 6. Trend Kelembapan AWS Borobudur

Kelembapan udara pada tanggal 8 Oktober hingga tanggal 15 Oktober 2018 menunjukkan bahwa kelembapan maksimum yang terukur pada AWS (Automatic Weather Station) Borobudur mencapai 96\% dengan rata-rata kelembapan udara sekitar $69-70 \%$ dan kelembapan minimum sebesar 22\%. Dari hasil pengukuran tersebut dapat disimpulkan bahwa kondisi kelembapan udara pada tanggal 8 Oktober hingga 15 Oktober 2018 rendah atau termasuk kategori kering dan dapat mendukung terjadinya kebakaran lahan dan hutan di Taman Nasional Gunung Merbabu.

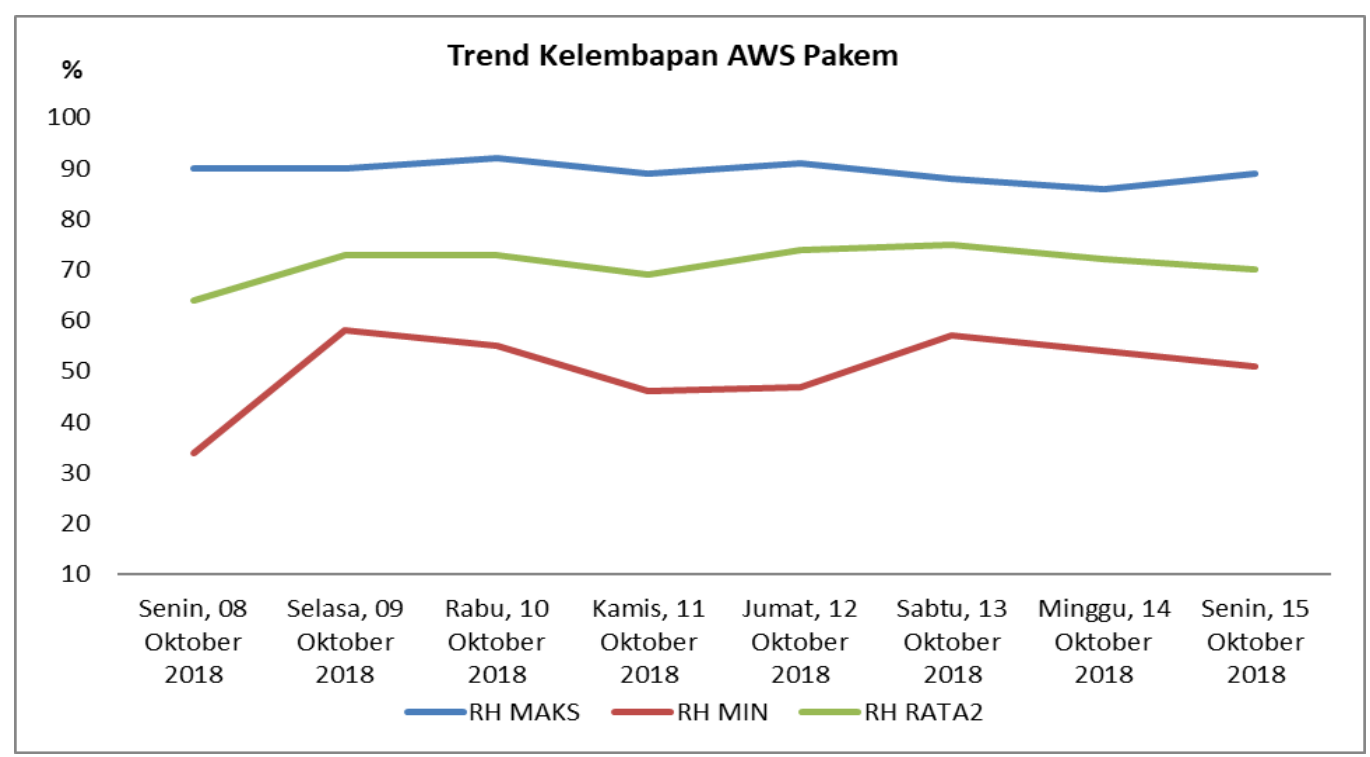

Gambar 7. Trend Kelembapan AWS Pakem

Kelembapan udara pada tanggal 8 Oktober hingga tanggal 15 Oktober 2018 menunjukkan bahwa kelembapan maksimum yang terukur pada AWS (Automatic Weather Station) Pakem mencapai 90\% dengan rata-rata kelembapan udara sekitar 64-70\% dan kelembapan minimum sebesar 34\%. Dari hasil pengukuran tersebut dapat disimpulkan bahwa kondisi kelembapan udara pada tanggal 8 Oktober hingga 15 Oktober 2018 rendah atau termasuk kategori kering dan dapat mendukung terjadinya kebakaran lahan dan hutan di Taman Nasional Gunung Merbabu. 


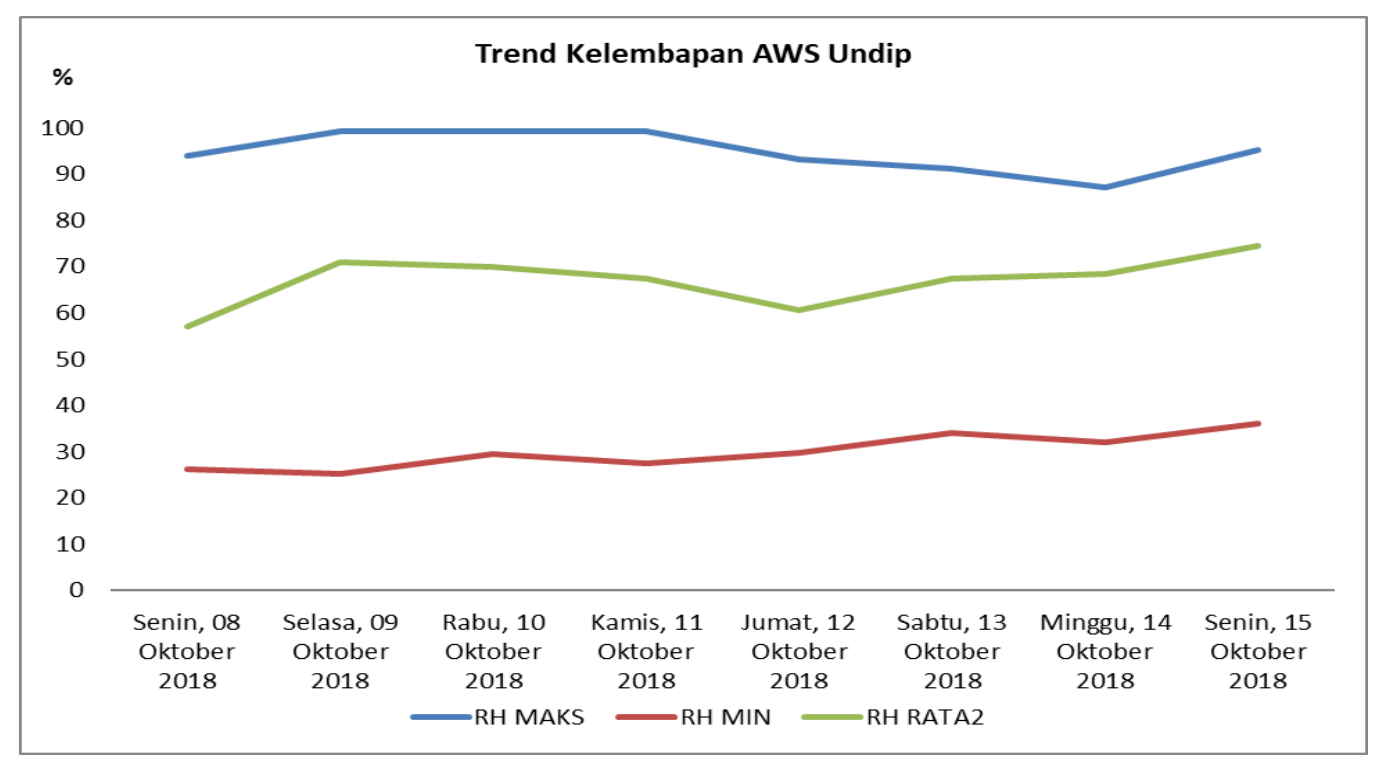

Gambar 8. Trend Kelembapan AWS Undip

Kelembapan udara pada tanggal 8 Oktober hingga tanggal 15 Oktober 2018 menunjukkan bahwa kelembapan maksimum yang terukur pada AWS (Automatic Weather Station) Undip mencapai 90\% dengan rata-rata kelembapan udara sekitar 57-70\% dan kelembapan minimum sebesar 25\%. Dari hasil pengukuran tersebut dapat disimpulkan bahwa kondisi kelembapan udara pada tanggal 8 Oktober hingga 15 Oktober 2018 rendah atau termasuk kategori kering dan dapat mendukung terjadinya kebakaran lahan dan hutan di Taman Nasional Gunung Merbabu.

Kelembapan relatif (Relative Humidity) merupakan istilah yang paling umum digunakan dalam dunia meteorologi sebagai penentu banyaknya kadar uap air dalam atmosfer. Pada tiga titik observasi dalam tulisan ini ketiganya memiliki kelembapan relatif maksimum yang cukup tinggi hingga mencapai $90 \%$, namun kelembapan maksimum di tiga titik tersebut hanya terjadi pada malam hingga dini hari dimana pada waktu tersebut memiliki tingkat radiasi matahari minimum sehingga kadar uap air di atmosfer yang tinggi pada malam hingga dini hari tidak mampu menghasilkan energi konvektif yang kuat untuk pembentukan awan hujan. Hal ini dapat disimpulkan bahwa kelembapan relatif yang tinggi pada malam hingga dini hari tanpa disertai adanya hujan tidak berdampak secara signifikan dalam menghambat terjadinya kebakaran hutan.

\subsubsection{Analisis Hari Tanpa Hujan (HTH)}

Curah hujan berpengaruh terhadap kelembaban bahan bakar. Septicorini (2006) memaparkan bahwa apabila curah hujan tinggi maka kelembaban bahan bakar di dalam hutan juga akan tinggi sehingga menyulitkan terjadinya kebakaran.

Hari Tanpa Hujan (HTH) adalah panjang maksimum dari hari tanpa hujan berturut-turut dengan $\mathrm{RR}<1 \mathrm{~mm}$, di mana $\mathrm{RRij}$ adalah jumlah presipitasi/curah hujan per hari-i dalam periode-j, kemudian dihitung jumlah terbesar hari tanpa hujan berturut-turut. 


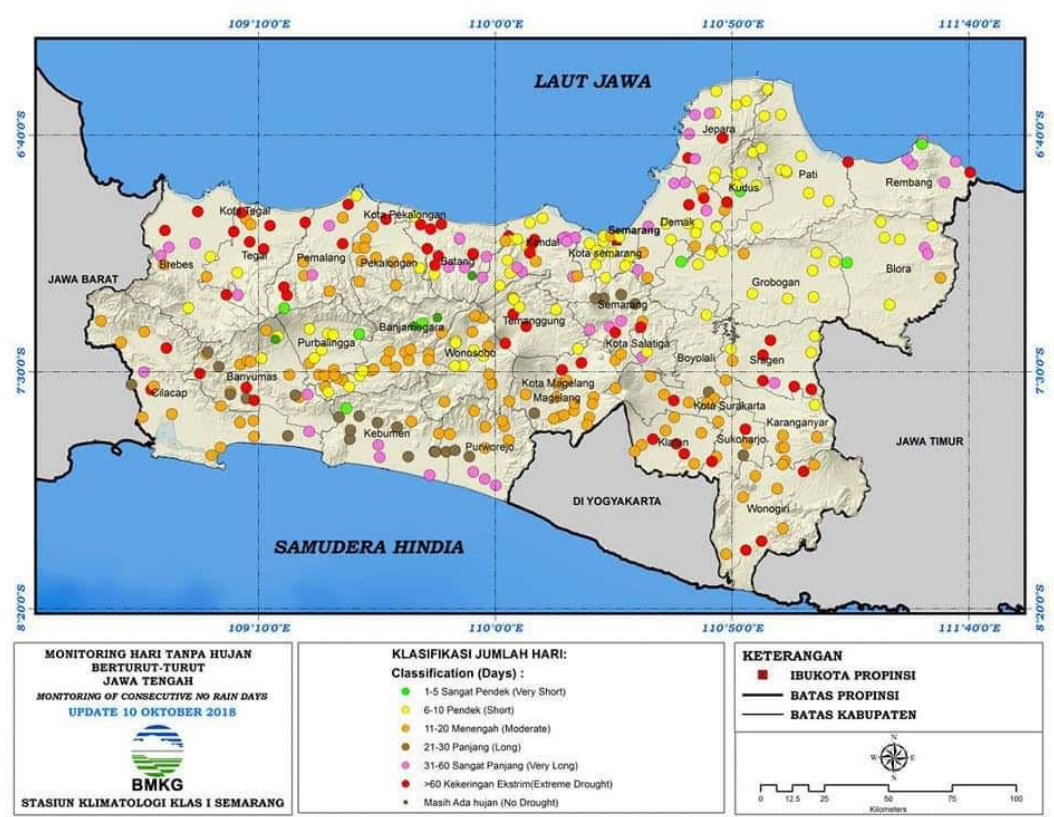

Gambar 9. Peta Sebaran Hari Tanpa Hujan per 10 Oktober (Sumber: Stasiun Klimatologi Klas 1 Semarang)

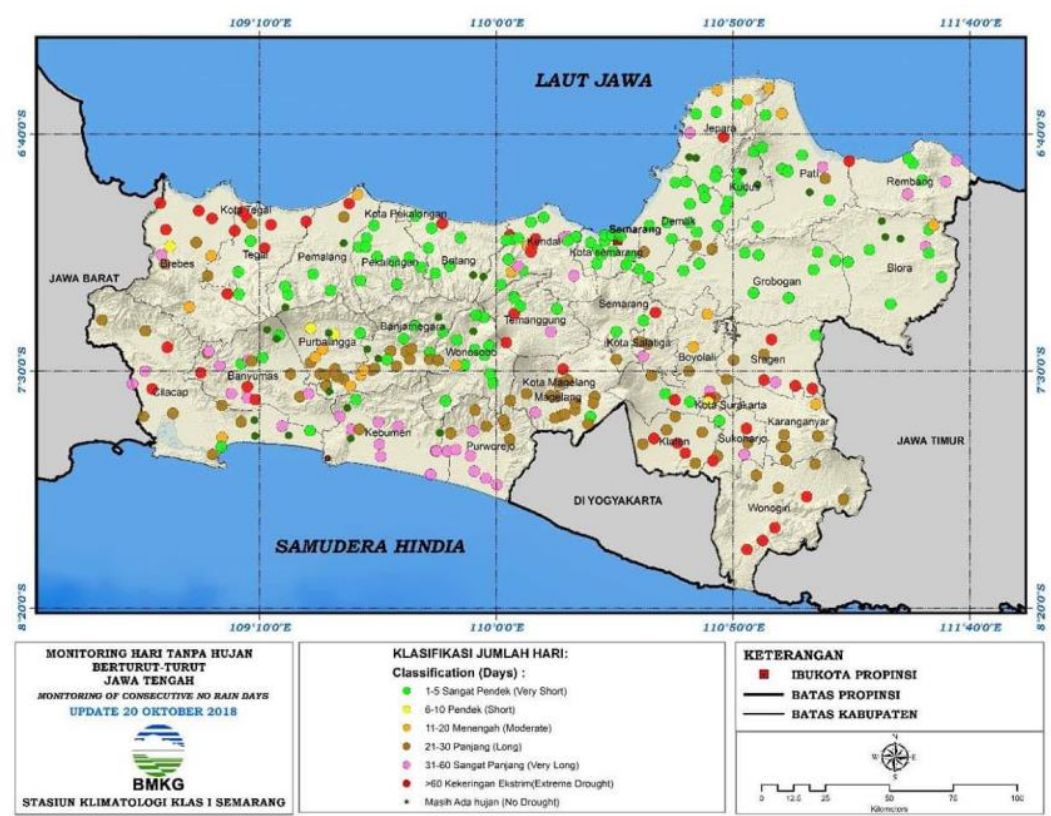

Gambar 10. Peta Sebaran Hari Tanpa Hujan per 20 Oktober (Sumber: Stasiun Klimatologi Klas 1 Semarang)

Berdasarkan peta sebaran Hari Tanpa Hujan (HTH) per tanggal 10 Oktober dan 20 Oktober 2018 yang didapat dari Stasiun Klimatologi Klas 1 Semarang, menunjukkan bahwa pada wilayah Taman Nasional Gunung Merbabu mengalami kategori Hari Tanpa Hujan panjang hingga kekeringan ekstrem yakni 20-60 Hari Tanpa Hujan yang dapat mendukung terjadinya kebakaran hutan dan lahan di Taman Nasional Gunung Merbabu. 


\subsubsection{Analisis Citra Satelit Himawari-8}

Analisis Citra Satelit Himawari-8 diolah menggunakan aplikasi SATAID dengan metode RGB (Red Green Blue) pada kanal 3,4, dan 6

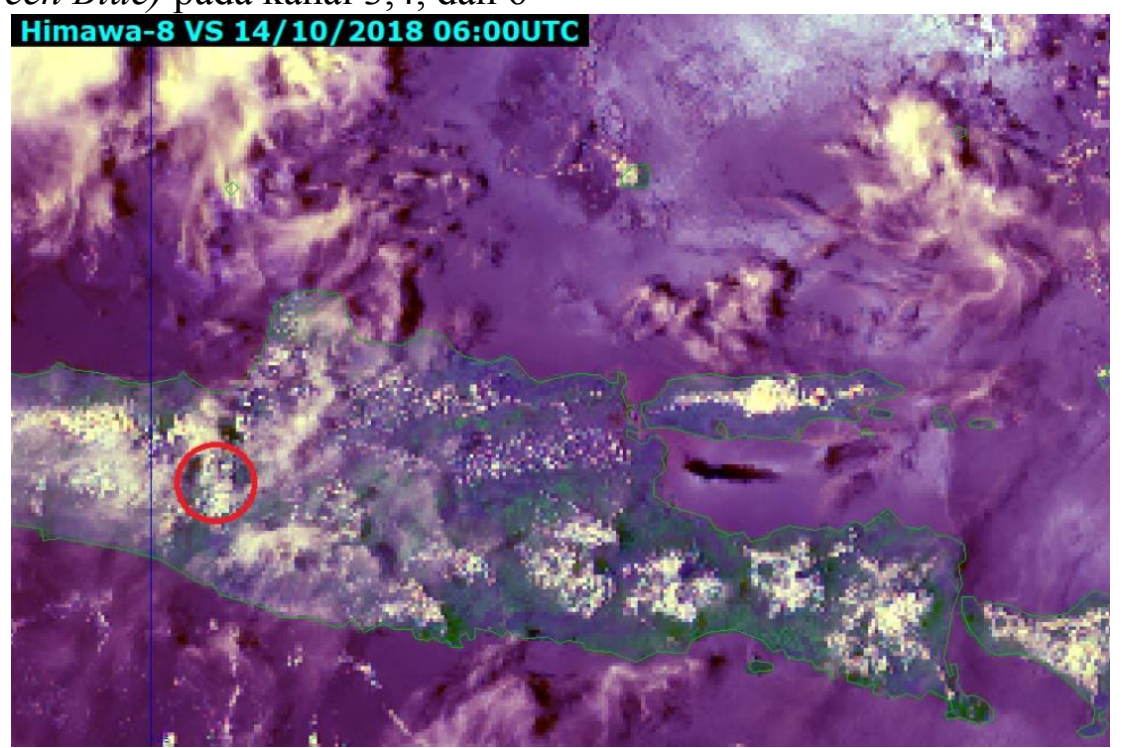

Gambar 11. Tampilan Citra Satelit Himawari-8 RGB 14 Oktober pukul 13.00 WIB

Pada tampilan Citra Satelit Himawari-8 tidak terdeteksi adanya titik api atau Hotspot. Hal tersebut dapat disebabkan kebakaran hutan dan lahan di Taman Nasional Gunung Merbabu belum memenuhi kriteria sebagai titik api atau Hotspot.

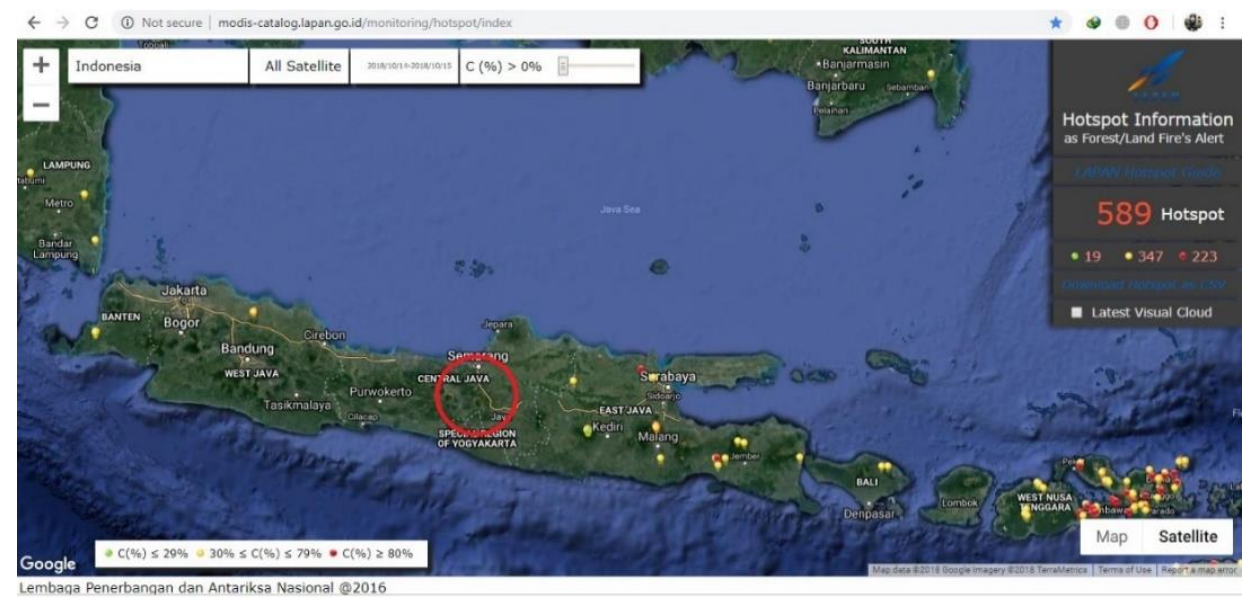

Gambar 12. Tampilan Peta Pantauan Titik Api LAPAN (Sumber: http://modiscatalog.lapan.go.id/monitoring/hotspot/index)

Titik api atau Hotspot juga tidak terdeteksi pada laman yang ditampilkan oleh LAPAN (Lembaga Penerbangan dan Antariksa Nasional). Hal tersebut dapat disebabkan kebakaran hutan dan lahan di Taman Nasional Gunung Merbabu belum memenuhi kriteria sebagai titik api atau Hotspot.

\section{KESIMPULAN}

Berdasarkan analisis yang dilakukan pada streamline angin permukaan, data AWS (Automatic Weather Station), peta sebaran Hari Tanpa Hujan (HTH) maka dapat disimpulkan 
bahwa faktor kekeringan meteorologi turut mendukung terjadinya kebakaran lahan dan hutan di Taman Nasional Gunung Merbabu. Pada tampilan Citra Satelit Himawari-8 dan peta sebaran titik api milik LAPAN tidak terlihat disebabkan kebakaran hutan dan lahan di Taman Nasional Gunung Merbabu belum memenuhi kriteria sebagai titik api/hotspot

\section{UCAPAN TERIMA KASIH}

Terima kasih penulis ucapkan kepada Kepala Stasiun Klimatologi Klas 1 Semarang yang telah memberikan informasi Hari Tanpa Hujan di wilayah Jawa Tengah dan kepada Kepala Sub-Bidang Pengelolaan Citra Satelit BMKG yang telah memberikan data satelit Himawari 8 serta kepada pegawai . Penelitian ini tidak menutup kemungkinan masih banyak terdapat kekurangan sehingga diharapkan dapat memberikan kritik dan saran yang membangun.

\section{DAFTAR PUSTAKA}

Bahri, S. (2002). Kajian Penyebaran Kabut Asap Kebakaran Hutan dan Lahan di Wilayah Sumatera Bagian Utara dan Kemungkinan Mengatasinya dengan TMC.Jurnal Sains \& Teknologi Modifikasi Cuaca, 3(2):99-104.

Chandler, C. (1983). Fire in Forestry: Volume I, Forest Fire Behavior and Effects. John Wiley

Sons, New York.

Gellert, P.K. (1998). A brief history and analysis of Indonesia's forest fire crisis. Southeast Asia Program Publications at Cornell University. Indonesia, vol 65: 63-85.

Gunarsih. 2001. Klimatologi Pengaruh Iklim Terhadap Tanah dan Tanaman. Jakarta: Bina Aksara

Rianawati, F. (2005). Kajian Faktor Penyebab dan Upaya Pengendalian Kebakaran Lahan Gambut oleh Masyarakat di Desa Salat Makmur Kalimantan Selatan. Jurnal Hutan Tropis Borneo No.17, September 2005: 51-59.

Septicorini, E.P. (2006). Studi Penentuan Tingkat Kerawanan Kebakaran Hutan di Kabupaten Ogan Komering Ilir Provinsi Sumatera Selatan, Skripsi, Departemen Manajemen Hutan Fakultas Kehutanan, Institut Pertanian Bogor, Bogor.

Syaufina, L., dan Sukmana, A. (2008). Tinjauan Penyebab Utama Kebakaran Hutan di Daerah Danau Toba. Laporan kajian kebakaran hutan di Danau Toba. Centre of Forest and Nature Conservation Research and Development (CFNCRD) dan International Tropical Timber Organization (ITTO)PD 394/06 REV.1 (F). Bogor. 